DOI: $10.47743 /$ jss-2021-67-4-10

\title{
Utilizarea blockchain în soluţionarea litigiilor
}

\author{
Blockchain Dispute Resolution
}

\section{Tudor-Matei Rusu ${ }^{1}$}

Rezumat: Nu prezintă o noutate faptul că persoanele, din dorinţa de a soluţiona cât mai rapid un litigiu, apelează cât mai des la mijloace alternative. Această situaţie este întâlnită, preponderent, în cazurile în care obiectul litigiului este unul relativ redus. Nici utilizarea platformelor online de soluţionare a litigiilor nu mai prezintă o noutate, acestea devenind din ce în ce mai folosite în ultima perioadă. Un aspect de noutate este reprezentat, însă, de utilizarea tehnologiei blockchain în soluţionarea litigiilor. Prin utilizarea acestei tehnologii, platformele online structurează întreaga procedură dar îi şi remunerează pe utilizatorii ce $\mathrm{au}$ rolul de a soluţiona litigiile. Totodată, tehnologia blockchain poate fi utilizată concomitent cu anumiţi algoritmi în aşa fel încât litigiile să fie soluţionate fără intervenţia factorului uman.

Cuvinte-cheie: blockchain; mijloace alternative de soluţionare a litigiilor; mijloace online de soluţionare a litigiilor; platforme de intermediere; Kleros

\begin{abstract}
The alternative dispute resolution methods $(A D R)$ are not something new, neither the online dispute resolution platforms $(O D R)$. In the last period of time more and more online platforms started to use blockchain to settle disputes. The blockchain technology is used by the platforms to set up arbitration, organize dispute adjudication and reward the arbitrators. Also, it can be used in a way which allows the disputing parties interact with each other through the platform, while the latter acts like a mediator, using algorithms that facilitate the interaction between the parties.
\end{abstract}

Keywords: blockchain; alternative dispute resolution methods (ADR); online dispute resolution methods (ODR); online platforms; Kleros

\section{Precizări introductive}

Mijloacele alternative de soluţionare a litigiilor nu mai prezintă o noutate. Astfel, de-a lungul timpului, în special din cauza supraîncărcării instanţelor statale, a existat o încercare de a încuraja metode precum medierea, concilierea, dispute board sau minitrial ${ }^{2}$.

${ }^{1}$ Doctorand, Facultatea de Drept, Universitatea „Alexandru Ioan Cuza” din Iași, e-mail: tmrusu@gmail.com.

${ }^{2}$ C.T. Ungureanu, Dreptul comerțului internațional, Editura Hamangiu, București, 2018, p. 312 . 
Datorită dezvoltării tehnologice, dar şi a expansiunii Internetului, unele dintre mijloacele alternative de soluţionare a litigiilor au fost transpuse în mediul online, apărând conceptul de Online Dispute Resolution (ODR). Acesta reprezintă o nouă modalitate alternativă de soluţionare a litigiilor ce presupune folosirea unei platforme online. În cadrul $O D R$, procesul de luare a unei decizii este facilitat de capacitatea de stocare şi de procesare a datelor de către calculatoare, dar şi de utilizarea Internetului ${ }^{3}$.

Participanţii beneficiază şi de o serie de garanţii specifice Internetului. Astfel, în cadrul procedurii de soluţionare alternativă a unui litigiu în mediul online pot fi instituite măsuri de siguranţă precum autentificarea utilizatorilor în doi factori ${ }^{4}$ şi criptarea informaţiilor transmise de către aceştia ${ }^{5}$.

$\mathrm{Nu}$ orice utilizare a tehnologiei cu scopul de a facilita soluţionarea unui litigiu presupune, în mod automat, şi folosirea unei metode alternative. Conceptul de $O D R$ presupune mai mult decât stocarea datelor în format electronic sau audierea unui martor prin videoconferinţă. Aceste două exemple reprezintă doar modalităţi în care tehnologia este folosită pentru a facilita bunul mers al justiţiei. Totodată, nici posibilitatea pe care o au unii consumatori ${ }^{6}$ de a trimite o plângere în format electronic societăţii de la care au achiziţionat un bun sau un serviciu nu presupune existenţa unui mijloc alternativ de soluţionare a litigiilor în cazurile în care acea plângere nu este dublată şi de existenţa unui sistem concret ce are rolul de a preîntâmpina o posibilă judecată. În această situaţie, plângerile consumatorilor

${ }^{3}$ R.D. Stângaciu, Limite ale implicării tehnologiei în soluționarea prin mijloace alternative a litigiilor Online Dispute Resolution prin prisma raporturilor de comerț internațional, în Analele Științifice ale Universității „Alexandru Ioan Cuza” Iași, Tomul LXV, Științe Juridice, 2019, Supliment, p. 161, [Online] la http://pub.law.uaic.ro/files/articole/ 2019/vols/11. stangaciu.pdf, accesat 10.11.2021; A. Gudkov, Crowd Arbitration: Blockchain Dispute Resolution, în Legal Issues in the Digital Age, Nr. 3, 2020, DOI: https:/doi.org/ 10.17323/2713-2749.2020.3.59.77, accesat 10.11.2021, p. 60 .

${ }^{4}$ Prin autentificarea în doi factori, utilizatorul trebuie să ofere două coduri de acces atunci când accesează respectiva platformă, iar acest lucru oferă o protecție suplimentară atât pentru propria persoană, cât şi pentru platforma accesată. A se vedea, L. Rosencrance, P. Loshin, M. Cobb, Two-factor authentication (2FA), [Online] la https://www.techtarget. com/searchsecurity/definition/two-factor-authentication, accesat 10.11.2021.

${ }^{5} \mathrm{~W}$. Gonzales, N. Masumy, Online Dispute Resolution Platforms: Cybersecurity Champions in the COVID-19 Era? Time for Arbitral Institutions to Embrace ODRs, în Kluwer Arbitration Blog, [Online] la http://arbitrationblog.kluwerarbitration.com/2020/09/ 25/online-dispute-resolution-platforms-cybersecurity-champions-in-the-covid-19-eratime-for-arbitral-institutions-to-embrace-odrs/, accesat 10.11.2021.

${ }^{6}$ Noțiunea de consumator poate fi definită, conform art. 2 pct. 2 din O.G. nr. 21/1992 privind protecția consumatorilor, republicată în M. Of. al României, Partea I, nr. 208 din 28 martie 2007, ca fiind „orice persoană fizică sau grup de persoane fizice constituite în asociații, care acționează în scopuri din afara activității comerciale, industriale sau de producție, artizanale ori liberale". 
se încadrează în sfera recenziilor pe care le cere societatea de la care au achiziţionat respectivul bun sau serviciu? ${ }^{7}$.

\section{Platformele Online Dispute Resolution (ODR Platforms)}

Odată cu apariţia conceptului de $O D R$ a apărut şi noţiunea de platformă $O D R$, deoarece modalitatea de soluţionare alternativă a litigiilor în mediul online este indisolubil legată de existenţa unei platforme.

O platformă $O D R$ este o pagină web ce oferă utilizatorilor săi posibilitatea de a se înregistra şi de a o utiliza cu scopul de a le fi soluţionat un posibil litigiu izvorât dintr-un contract încheiat în mediul online. Deşi modul de funcţionare diferă de la o platformă la alta, de regulă, utilizatorii accesează acest mod de soluţionare alternativă a litigiilor prin completarea unui formular tipizat în cadrul platformei şi, totodată, ei trebuie să ataşeze documentele prin care îşi justifică pretenţiile ${ }^{8}$.

În contextul creşterii numărului de procese dintre participanţii la activităţile de comerţ online, a devenit evident că era necesară o modalitate eficientă şi rapidă de soluţionare a acestor categorii de litigii. Una dintre primele platforme de intermediere ce a oferit utilizatorilor săi şi o secţiune dedicată soluţionării amiabile a litigiilor a fost $e B a y^{9}$.

Serviciile oferite de platformele online de soluţionare a litigiilor sunt adaptate la caracteristicile Internetului, oferind utilizatorilor, ce se află la distanţă unul faţă de altul, mijloacele necesare pentru a-şi comunica cererile şi dovezile. Totodată, platformele $O D R$ nu aduc o schimbare semnificativă faţă de mijloacele alternative de soluţionare a litigiilor, ele doar transpun aceste mijloace în mediul online $^{10}$.

Nu doar platformele de intermediere au urmărit dezvoltarea unor centre online de soluţionare alternativă a litigiilor, inclusiv autorităţile publice au considerat necesară existenţa unor astfel de metode. Platformele $O D R$, în funcţie de entitatea ce le pune la dispoziţie, pot fi clasificate în platforme private şi publice ${ }^{11}$.

${ }^{7}$ A.H. Raymond, S.J. Shackelford, Technology, Ethics, and Access to Fustice: Should an Algorithm be Deciding Your Case?, în Michigan Journal of International Law, Vol. 35, Nr. 3, 2014, p. 500, [Online] la http://repository.law.umich.edu/mjil/vol35/iss3/1, accesat 10.11.2021.

${ }^{8} \mathrm{~J}$. Barnett, P. Treleaven, Algorithmic Dispute Resolution - The Automation of Professional Dispute Resolution Using AI and Blockchain Technologies, în The Computer Journal, Section C: Computational Intelligence, Machine Learning and Data Analytics, Vol. 61, Nr. 3, 2018, DOI: https://doi.org/10.1093/comjnl/bxx103, accesat 10.11.2021, p. 403.

${ }^{9}$ M. Dylag, H. Smith, From cryptocurrencies to cryptocourts: blockchain and the financialization of dispute resolution platforms, în Information, Communication \& Society, p. 3, [Online] la https://www.tandfonline.com/doi/full/10.1080/13691 18X.2021.1942958, accesat 13.11.2021.

${ }^{10}$ Idem, p. 4.

${ }^{11}$ A.H. Raymond, S.J. Shackelford, op. cit., p. 501. 
Cele private, care sunt puse la dispoziţie de către o întreprindere ${ }^{12}$, pot fi subclasificate în funcţie de serviciile oferite utilizatorilor. O primă categorie este reprezentată de platformele self-contained, care nu există de sine stătător, ci fac parte dintr-o comunitate deja existentă şi au rolul de a soluţiona litigii în cadrul acesteia. Astfel, cel mai bun exemplu este reprezentat de centrul de soluţionare a litigiilor din cadrul platformei $e B a y^{13}$. Rolul acestui centru este de a facilita comunicarea dintre cumpărător şi vânzător în cazul în care există probleme cu privire la contractul intermediat de platformă. În momentul în care una dintre părţile contractului este nemulţumită de modul în care cealaltă a executat obligaţiile, poate să apeleze la acest centru de soluţionare a litigiilor. Odată începută procedura, părţile au la dispoziţie un termen de trei zile în care pot ajunge la un consens, iar din momentul în care este împlinit termenul şi acestea nu au ajuns la un consens, oricare dintre ele poate apela la un reprezentat al platformei pentru soluţionare ${ }^{14}$.

$\mathrm{Nu}$ trebuie făcută confuzia între funcţiile de soluţionare alternativă a litigiilor din cadrul platformelor de intermediere cu posibilitatea pe care o au utilizatorii de a posta recenzii negative la adresa vânzătorilor. Prin simplul fapt că oferă o recenzie, cumpărătorul nu urmăreşte şi soluţionarea pe cale amiabilă a problemei pe care o are referitoare la modul în care vânzătorul a executat obligaţiile asumate prin contract.

Un avantaj al acestui tip de platforme este acela că, în cadrul sistemului deja existent, pot fi luate şi alte măsuri în afară de soluţionarea alternativă a litigiilor. Astfel, platforma poate suspenda contul unui vânzător dacă împotriva acestuia există un anumit număr de plângeri în cadrul centrului de soluţionare a litigiilor. Totodată, inclusiv mecanismul de plată este structurat în aşa fel încât plata are loc prin intermediul mijloacelor puse la dispoziţie de platformă şi, dacă se constată că vânzătorul nu şi-a respectat obligaţiile, platforma poate dispune, în baza acordului încheiat cu utilizatorul-vânzător, ca suma plătită să fie returnată de către acesta din urmă în cazul în care se ajunge la o soluţie prin intermediul centrului de soluţionare a litigiilor ${ }^{15}$.

O a doua categorie este reprezentată de platformele full service. Acestea au o existenţă de sine stătătoare şi, astfel, nu se mai limitează la o anumită comunitate deja existentă şi oferă acces oricărei persoane la serviciile lor. Spre deosebire de cele self-contained, acestea nu mai oferă şi alt serviciu utilizatorilor, soluţionarea online a litigiilor fiind singurul lor obiect de activitate. Un bun exemplu este platforma Modria ${ }^{16}$. Atunci când un utilizator apelează la serviciile oferite de

12 Este folosită noțiunea de întreprindere, deoarece, conform art. 3 alin. (2) din Codul civil român (republicat în M. Of. al României, Partea I, nr. 505 din 15 iulie 2011), „sunt considerați profesioniști toți cei care exploatează o întreprindere.”.

${ }^{13}$ A se vedea, eBay Resolution Center, [Online] la https://resolutioncenter.ebay.com/, accesat 13.11.2021.

${ }^{14}$ A.H. Raymond, S.J. Shackelford, op. cit., p. 501.

${ }^{15}$ Idem, p. 502.

16 [Online] la https://www.tylertech.com/products/Modria, accesat 15.11.2021. 
aceasta, trebuie să ofere toate detaliile şi dovezile necesare, iar, platforma, în baza unor algoritmi, sugerează o soluţie părţilor. Totodată, acestea pot să şi comunice prin intermediul platformei şi, dacă nu ajung la un consens în baza soluţiei generate automat, ele sunt îndemnate să apeleze la procedura medierii, procedură ce are loc, dacă părţile doresc, tot în cadrul platformei ${ }^{17}$.

De-a lungul timpului, platformele $O D R$ s-au confruntat cu o problemă legată de costurile proprii. Astfel, costurile ocazionate de acestea erau vădit disproporţionate comparativ cu valoarea obiectelor litigiilor ce erau soluţionare prin intermediul lor ${ }^{18}$. Dar, evoluţia tehnologică, a făcut posibilă eliminarea celui mai costisitor element, factorul uman. În acest sens, platformele $O D R$ au început, treptat, să îşi automatizeze tot mai mult procedurile, apelând la algoritmi ${ }^{19}$.

În prezent, în cadrul platformelor Modria, SmartSettle ${ }^{20}$ şi CyberSettle $e^{21}$ atât procedurile de negociere, cât şi cele de mediere se desfăşoară fără intervenţia factorului uman. În cazul negocierii, sunt oferite mijloace de comunicare părţilor, iar în cazul medierii, sunt utilizaţi algoritmi ce găsesc o soluţie ce este, mai apoi, comunicată părţilor, urmând ca acestea să decidă dacă sunt sau nu de acord cu soluţia identificată ${ }^{22}$.

\section{Blockchain Dispute Resolution (BDR)}

Asemenea $O D R$ şi $B D R$ reprezintă o metodă de soluţionare alternativă a litigiilor ce este indisolubil legată de existenţa unei platforme online, doar că, spre deosebire de mijloacele discutate anterior, $B D R$ foloseşte tehnologia blockchain în procesul de soluţionare alternativă a litigiilor.

\subsection{Definirea termenilor de blockchain şi blockchain dispute resolution}

Tehnologia blockchain reprezintă o modalitate de stocare a datelor într-un sistem descentralizat, ce face, datorită caracteristicilor sale, foarte dificilă sau chiar imposibilă modificarea datelor prin accesarea neautorizată a sistemului. Practic, blockchain-ul presupune o bază de date descentralizată, alcătuită dintr-o multitudine de calculatoare, interconectate ce au rolul de a stoca date simultan, în aşa fel încât fiecare dată stocată să fie găsită în fiecare calculator din sistem ${ }^{23}$.

Având o structură descentralizată şi interconectată, blockchain-ul prezintă mult mai multă siguranţă faţă de o bază de date obişnuită, aceasta bazându-se pe o singură sursă de stocare a datelor. Totodată, de fiecare dată când se doreşte

17 A.H. Raymond, S.J. Shackelford, op. cit., p. 503; J. Barnett, P. Treleaven, op. cit., p. 404.

${ }^{18}$ Este de natura soluționării alternative a litigiilor ca la aceste metode să se apeleze, în special, în cazul litigiilor de o importanță mai redusă.

${ }^{19}$ A.H. Raymond, S.J. Shackelford, op. cit., p. 514.

20 [Online] la https://www.smartsettle.com/, accesat 15.11.2021.

21 [Online] la http://www.cybersettle.com/, accesat 15.11.2021.

${ }^{22}$ J. Barnett, P. Treleaven, op. cit., p. 404.

${ }^{23}$ A se vedea, What is blockchain?, [Online] la https://www.euromoney.com/learning/ blockchain-explained/what-is-blockchain, accesat 15.11.2021. 
înregistrarea unei noi informaţii în sistem, este necesar acordul tuturor calculatoarelor interconectate, iar acest lucru sporeşte gradul de transparenţă $\breve{a}^{24}$.

Tehnologia blockchain a apărut ca o reacţie contra autorităţii statale şi a fost şi folosită cu scopul de a mai reduce din implicarea statului în anumite domenii în care se considera că acesta deţine o putere absolută ${ }^{25}$. In acelaşi timp, progresul tehnologic şi expansiunea Internetului au stat întotdeauna la baza soluţionării litigiilor în mediul online, iar tehnologia blockchain nu face excepţie, putând reprezenta o nouă soluţie pentru mijloacele alternative de soluţionare a litigiilor.

Termenul blockchain dispute resolution este folosit pentru a descrie o procedură descentralizată de soluţionare alternativă a litigiilor, desfăşurată în mediul online, ce utilizează tehnologia blockchain pentru a organiza procesul de soluţionare şi de executare a hotărârii luate, dar şi pentru a-i remunera pe cei care iau hotărârea ${ }^{26}$.

Alternativ, pentru a descrie acelaşi mod de soluţionare a litigiilor, sunt utilizate noţiunile de crypto instanţe şi crowdsourced dispute resolution ${ }^{27}$. Ultimul dintre termeni este utilizat pentru a face referire la persoanele care soluţionează litigiile. În cadrul acestei metode, persoanele ce urmează să soluţioneze un litigiu nu trebuie să aibă o calitate anume, oricine doreşte poate să participe la o astfel de procedură. Mai mult decât atât, persoanele care soluţionează litigiul nu doar că nu trebuie să îndeplinească nicio cerinţă, dar sunt şi necunoscute părţilor. De aici şi reiese termenul de crowdsourced dispute resolution, deoarece rolul decizional este transferat unui număr foarte mare de persoane, a căror provenienţă este necunoscută şi cărora nu li se cere nicio cunoştinţă juridică ${ }^{28}$.

Din acest punct de vedere, soluţionarea litigiilor prin utilizarea tehnologiei blockchain se deosebeşte nu doar de situaţia în care se apelează la instanţele statale sau arbitrale, ci şi de celelalte metode alternative de soluţionare a litigiilor, deoarece, inclusiv în cadrul acestora, persoana ce soluţionează litigiul este cunoscută de părţi, dacă nu este chiar aleasă de către acestea.

A existat, totodată, şi o iniţiativă de a utiliza tehnologia blockchain în cadrul procedurilor judiciare desfăşurate în faţa instanţelor statale. Astfel, în Marea Britanie, prin intermediul unui program pilot ce a debutat în anul $2018 \mathrm{~s}-\mathrm{a}$ analizat dacă activitatea de stocare a documentelor poate fi realizată prin intermediul unei baze de date blockchain ${ }^{29}$.

${ }^{24}$ J. Barnett, P. Treleaven, op. cit., p. 403.

${ }^{25}$ V. Gupta, A Brief History of Blockchain, în Harvard Business Review, [Online] la https://hbr.org/2017/02/a-brief-history-of-blockchain, accesat 15.11.2021.

${ }^{26}$ A. Gudkov, op. cit., p. 60.

${ }^{27}$ Idem, p. 62.

28 A. Gudkov, op. cit., p. 62.

${ }^{29}$ M. Dylag, H. Smith, op. cit., p. 5; S. Seth, UK Courts Start Pilot Blockchain Evidence System, [Online] la https://www.investopedia.com/news/uk-courts-start-pilot-blockchainevidence-system/, accesat 16.11.2021. 


\subsection{Clasificarea platformelor $B D R$}

Asemenea platformelor $O D R$ şi platformele ce utilizează tehnologia blockchain într-un proces de soluţionare alternativă a litigiilor pot fi clasificate în funcţie de principalul serviciu pus la dispoziţia utilizatorilor. Astfel, această activitate poate fi singura pe care o desfăşoară platforma sau poate să reprezinte un serviciu adiţional celui principal, pus la dispoziţia propriilor utilizatori ${ }^{30}$.

În cazul în care activitatea de soluţionare a litigiilor reprezintă singurul serviciu oferit de platformă, aceasta nu se bazează pe o comunitate deja existentă. Astfel, oricine poate să apeleze la respectivul serviciu pus la dispoziţie pentru a-i fi soluţionat un litigiu izvorât dintr-un contract încheiat în mediul online. Este posibil, cu toate acestea, să fie introduse filtre cu privire la litigiile ce pot fi soluţionate. Platformele Kleros ${ }^{31}$, Rhubarb ${ }^{32}$ şi Aragon $^{33}$ sunt unele dintre cele ce oferă acces la serviciile lor de soluţionare alternativă a litigiilor tuturor persoanelor doritoare şi a căror litigii respectă anumite condiţii ce diferă de la o platformă la alta $^{34}$.

Deşi acestea nu se bazează pe o comunitate deja existentă deoarece nu oferă decât serviciul de soluţionare a litigiilor, în mod automat, ele se adresează unei sfere bine stabilite de persoane, unui ecosistem identificabil. Astfel, este normal ca, prin utilizarea blockchain-ului să se urmărească atragerea persoanelor ce sunt familiarizate cu acest fenomen şi care intră în contact cu respectiva tehnologie. Spre exemplu, Kleros oferă posibilitatea de a apela la serviciile sale numai persoanelor fizice sau întreprinderilor ce au încheiat un smart contract ce respectă condiţiile prevăzute în mod expres în cadrul platformei ${ }^{35}$.

Există posibilitatea ca unele platforme să ofere, pe lângă serviciile principale puse la dispoziţia utilizatorilor, şi o modalitate de soluţionare alternativă a litigiilor dintre aceştia, iar această metodă să fie pusă în aplicare prin intermediul tehnologiei blockchain. În acest caz, datorită principalului serviciu pus la dispoziţie, există o comunitate bine închegată, iar, în cadrul acesteia, pot apărea probleme referitoare la modul în care părţile îşi execută obligaţiile contractuale. În astfel de situaţii, activitatea de soluţionare alternativă a litigiilor presupune un serviciu adiţional pus la dispoziţia utilizatorilor ${ }^{36}$.

Întreprinderea din China, Baidu $u^{37}$, ce oferă utilizatorilor săi un motor de căutare, dar şi alte servicii ce ţin de domeniul Internetului, a dezvoltat, în colaborare cu Comisia Arbitrală din Qingdao, un sistem de soluţionare a litigiilor în mediul online, sistem ce utilizează tehnologia de tip blockchain pentru a stoca şi transmite

\footnotetext{
${ }^{30}$ A. Gudkov, op. cit., p. 62.

31 [Online] la https://court.kleros.io/, accesat 16.11.2021.

32 [Online] la https://www.rhucoin.com/, accesat 16.11.2021.

33 [Online] la https://anj.aragon.org/\#/dashboard, accesat 16.11.2021.

34 A. Gudkov, op. cit., p. 62.

35 [Online] la https://github.com/kleros, accesat 16.11.2021.

${ }^{36}$ A. Gudkov, op. cit., p. 63.

37 [Online] la http://www.baidu.com/, accesat 17.11.2021.
} 
informaţii ${ }^{38}$. Şi platforma de intermediere Alibaba $^{39}$ a dezvoltat un serviciu adiţional, bazat pe tehnologia blockchain, ce are rolul de a le permite propriilor utilizatori să îşi rezolve litigiile apărute în legătură cu contractele încheiate în cadrul platformei.

\subsection{Avantajele şi dezavantajele $B D R$}

O metodă alternativă de soluţionare a litigiilor, ce utilizează blockchain-ul şi se adresează, cu precădere, litigiilor izvorâte din contracte încheiate în mediul online, este de aşteptat să presupună atât avantaje, cât şi dezavantaje pentru cei ce doresc să apeleze la aceasta.

Din moment ce întreaga procedură presupune o soluţionare descentralizată a litigiilor, majoritatea avantajelor şi a dezavantajelor sunt generate de faptul că, spre deosebire de situaţia instanţelor statale sau arbitrale, soluţia este luată fie în baza unor algoritmi, fie de către persoane necunoscute.

\subsubsection{Avantajele $\mathrm{BDR}$}

Un prim avantaj este reprezentat de faptul că, datorită modului în care este gândită procedura, este imposibilă identificarea utilizatorilor ce au rolul de a soluţiona litigiile. Astfel, nu este niciodată făcută publică identitatea acestora, în cadrul platformei fiind cunoscută doar crypto adres $a^{40}$, pseudonimul sau adresa de email. Practic, litigiul este soluţionat de către mai mulţi utilizatori anonimi, iar nici aceştia nu pot să cunoască persoana celuilalt. Astfel, decizia este luată de către persoane ce nu se cunosc, nu au încredere una în cealaltă şi nici nu cunosc persoanele al cărui litigiu îl tranşează, acest lucru facând ca accentul să fie pus pe problemă în sine şi nu pe părţii1.

Deşi persoanele sunt necunoscute, anonime, istoricul acestora referitor la litigiile soluţionate anterior poate fi verificat prin intermediul crypto adresei. Iar din moment ce toate datele referitoare la istoricul persoanei în cadrul ecosistemului sunt transparente şi pot fi verificate de către participanţii la procedură, se reduce din riscul creat de faptul că identitatea sa nu este cunoscută de aceştia ${ }^{42}$.

Un al doilea avantaj este reprezentat de modul în care are loc punerea în aplicare a deciziei luate. Spre deosebire de situaţia în care litigiul este soluţionat de către instanţele statale sau arbitrale, în cadrul $B D R$ nu mai este necesară nicio acţiune din partea părţii ce nu a avut câştig de cauză. Totodată, nu mai este

38 A. Gudkov, op. cit., p. 63; M. Wood, Baidu launches judicial arbitration blockchain, [Online] la https://www.ledgerinsights.com/baidu-judicial-arbitration-blockchain/, accesat 17.11.2021.

39 [Online] la https://www.alibaba.com/?spm=a27aq.22871746.scGlobalHomeHeader.8. 13ae3bdbBUwVJ1, accesat 17.11.2021.

${ }^{40}$ Crypto adresa presupune un șir de caractere (atât litere, cât și cifre) ce are rolul de a identifica titularul unui cuantum de cryptomonedă. Este imposibil ca două persoane să aibă aceeași crypto adresă. A se vedea, What Is My Bitcoin Address and How Does It Work?, [Online] la https://unblock.net/bitcoin-address-work/, accesat 18.11.2021.

${ }^{41}$ A. Gudkov, op. cit., p. 63.

${ }^{42}$ Ibidem. 
necesară nici apelarea la forţa de constrângere a statului pentru a o obliga pe una dintre părţi să execute silit hotărârea, în cazul în care aceasta nu a executat hotărârea de bunăvoie. În această situaţie, soluția luată este pusă în executare în mod automat de către platformă. Executarea are loc imediat prin intermediul unui smart contract ${ }^{43}$ încheiat între părţi la începutul procedurii ${ }^{44}$.

Alternativ termenului de blockchain dispute resolution, pentru a descrie aceeaşi metodă alternativă de soluţionare a litigiilor, este folosită şi noţiunea de crowdsourced dispute resolution, aşa cum deja am menţionat. Astfel, se pune accentul pe numărul mare şi, oarecum, aleatoriu al celor ce pot soluţiona litigii prin intermediul unei astfel de proceduri. Unii autori chiar aseamănă această metodă cu modul în care curţile cu juraţi soluţionează un litigiu ${ }^{45}$.

Teoretic, cu cât numărul celor ce soluţionează un litigiu este mai mare, şansele ca aceştia să ajungă la o concluzie greşită sunt din ce în ce mai mici. Totodată, deciziile sunt luate, de regulă, fără o colaborare între cei ce tranşează problema, iar acest lucru scade, la rândul său, riscul ca utilizatorii platformei să ajungă la o decizie greşită, deoarece ei nu se pot influenţa reciproc. Din aceste motive este utilizat şi termenul de wisdom of the crowd pentru a descrie modul în care sunt luate hotărârile în cadrul unei astfel de metode de soluţionare a litigiilor ${ }^{46}$.

Metoda devine ineficientă în cazul în care numărul celor ce soluţionează litigiile este redus. Dar, din moment ce fiecare caz aparte diferă şi procedurile stabilite de fiecare platformă diferă la rândul lor, este dificil de stabilit ce presupune un număr redus de persoane raportat la fiecare caz în parte. Spre exemplu, în cadrul centrului de soluţionare alternativă a litigiilor pus la dispoziţie de platforma Alibaba, litigiile sunt soluţionate în cadrul unor paneluri la care iau parte 31 de persoane. Totodată, numărul de cauze pe care le poate soluţiona un utilizator întro zi este limitat la $20^{47}$. În cadrul platformei Kleros, litigiile sunt soluţionate de către un număr de trei sau de cinci persoane, în funcţie de obiectul litigiuluii ${ }^{48}$.

Diferenţa dintre cele două exemple anterioare este dată de faptul că, în cadrul Kleros, litigiile tind să prezinte un grad mai mare de dificultate, soluţionarea acestora luând şi mai mult timp. Spre exemplu, jumătate dintre cei ce folosesc platforma consideră că pot soluţiona zilnic între două şi cinci cauze. În acelaşi timp, utilizatorii Kleros tind să fie şi mai bine pregătiţi comparativ cu utilizatorii altor platforme asemănătoare. Conform unui studiu, $86 \%$ dintre utilizatori sunt capabili

${ }^{43}$ Termenul de smart contract presupune, de fapt, un program redactat în limbaj informativ ce este înregistrat într-o bază de date de tip blockchain. A se vedea, What are smart contracts on blockchain?, [Online] la https://www.ibm.com/topics/smart-contracts, accesat 18.11.2021.

${ }^{44}$ A. Gudkov, op. cit., p. 64.

45 Ibidem.

${ }^{46}$ A. Gudkov, op. cit., p. 65.

${ }^{47}$ D. Dimov, Crowdsourced online dispute resolution, în Leiden University Center for Law and Digital Technologies, [Online] la https://papers.ssrn.com/sol3/papers.cfm? abstract_id $=3003815$, accesat 20.11.2021.

48 A. Gudkov, op. cit., p. 67. 
să rezolve exerciţii de logică dificile şi complexe, iar peste $80 \%$ dintre aceştia sunt familiarizaţi cu termenii juridici ce pot fi întâlniţi în timpul soluţionării litigiilor ${ }^{49}$.

Un alt avantaj este reprezentat de faptul că oricine poate să apeleze la această modalitate de soluţionare a litigiilor. Platformele nu limitează utilizatorii la o anumită zonă geografică şi, totodată, nu doar cei ce folosesc tehnologia blockchain pot să apeleze la serviciile oferite de acestea. Practic, oricine acceptă condiţiile platformei poate să ceară să îi fie soluţionată problema astfel.

Un ultim avantaj este cel legat de eficienţă. Astfel, $B D R$ reprezintă o soluţie în special pentru cazurile în care obiectul litigiului are o valoare relativ redusă. Durata procedurilor desfăşurate în faţa instanţelor statale sau în faţa instanţelor arbitrale tinde să fie una destul de mare şi în cazul în care litigiul are o importanţă relativ redusă nu este utilă aşteptarea unui timp îndelungat pentru ca problema să fie soluţionată. Dar, în cazul unui litigiu important, a cărui obiect are o valoare semnificativă, $B D R$ nu mai reprezintă o soluţie la fel de viabilă. Indiferent de costurile procedurii sau de durata în care se ia o soluţie, părţile ar trebui să dorească, în special, soluţionarea temeinică a cauzei şi nu rezolvarea ei cât mai rapid.

\subsubsection{Dezavantajele BDR}

Deciziile sunt luate, în cadrul acestei metode, de către mai multe persoane şi acest lucru reprezintă, la o primă vedere, un avantaj, mulţi autori făcând inclusiv referire, aşa cum am arătat mai sus, şi la termenul de wisdom of the crowd ${ }^{50}$. Dar, deciziile nu sunt luate în urma consultării dintre utilizatori. Între aceştia nu există nicio formă de dialog pe toată durata procedurii şi, astfel, din moment ce ei nu se pot influenţa reciproc, metoda de soluţionare nu apelează cu adevărat la înţelepciunea utilizatorilor. O decizie colectivă presupune o colaborare între persoanele ce urmează să o ia, iar în cazul în care există opinii divergente, ele pot încerca să se influenţeze reciproc, dar acest lucru este exclus în cadrul BDR. În situaţia în care decizia este luată, prin vot majoritar, dar fără ca decidenţii să se poată consulta, aceasta nu mai este una colectivă. Deşi utilizatorii nu comunică între ei în timpul deliberării, acest lucru nu presupune în mod automat că decizia este una greşită, dar, din moment ce ei nu încearcă să ajungă la un punct comun, cresc şansele ca decizia să nu fie corectă ${ }^{51}$. Spre exemplu, în cadrul Kleros, deciziile sunt luate fără ca utilizatorii să poată comunica între ei iar modul în care ei sunt remuneraţi chiar încurajează această lipsă de comunicare ${ }^{52}$.

În cazul soluţionării unui litigiu de către instanţele statale sau arbitrale, legitimitatea soluţiilor este generată şi de imparţialitatea judecătorilor sau a arbitrilor. În cadrul procedurilor desfăşurate în faţa instanţelor statale, atunci când judecătorul nu oferă suficiente garanţii referitoare la imparţialitatea sa, oricare

\footnotetext{
49 Ibidem.

${ }^{50}$ A. Gudkov, op. cit., p. 65.

${ }^{51}$ Idem, p. 69.

${ }^{52}$ A se vedea infra, 2.4. Modul în care sunt soluţionate litigiile în cadrul platformei Kleros.
} 
dintre părţi poate formula o cerere de recuzare împotriva acestuia ${ }^{53}$. Inclusiv arbitrii aleşi să soluţioneze un litigiu pot fi înlocuiţi în cazul în care nu oferă toate garanţiile cu privire la imparţialitatea sau la independenţa lor ${ }^{54}$.

Spre deosebire de aceste situaţii, în cadrul $B D R$, părţile nici nu cunosc persoana celui ce soluţionează litigiul. Utilizatorii se diferenţiază unul de celălalt prin intermediul crypto adresei. Dar, un utilizator poate avea mai multe astfel de adrese şi, astfel, se poate înrola în cadrul unei platforme de mai multe ori şi, dacă este repartizat, poate să soluţioneze un litigiu ca şi cum decizia ar fi luată de mai multe persoane. Asemenea acţiuni sunt cunoscute şi sub numele de sybil attacks ${ }^{55}$. Lipsa oricărui mecanism de verificare a utilizatorilor nu oferă nicio garanţie celor ce doresc soluţionare litigiilor prin această procedură că nu se vor confrunta cu o asemenea problemă ${ }^{56}$.

Pe lângă riscul ca un singur utilizator să soluţioneze un litigiu folosind mai multe crypto adrese, din cauza faptului că utilizatorii sunt anonimi, există un risc şi mai mare cu privire la influenţarea lor de către una dintre părţi. Tocmai şi din acest motiv, Kleros oferă posibilitatea părţilor de a ataca hotărârea luată de către utilizatori, iar în cadrul căii de atac numărul acestora se va majora, acest lucru oferind o protecţie suplimentară împotriva influenţării utilizatorilor de către părţi ${ }^{57}$.

Un alt dezavantaj este reprezentat de faptul că litigiile tind să fie soluţionate fără ca utilizatorii să interpreteze sau să aplice nicio normă de drept. Astfel, în cadrul comunităţilor blockchain, părţile unui litigiu provin, cel mai probabil, din state diferite. În mod normal, acest lucru ar aduce modificări foarte importante litigiului, modificări reprezentate, în special, de modul în care părţile au ales sau nu o lege aplicabilă litigiului şi o instanţă competentă. Dar, în cadrul unor asemenea comunităţi, oricum există o încercare de a limita cât mai mult ordinea statală şi,

${ }^{53}$ Conform art. 44 alin. (1) din Legea nr. 134/2010 privind Codul de procedură civilă (republicată în M. Of. al României, Partea I, nr. 247 din 10 aprilie 2015), ,judecătorul aflat într-o situație de incompatibilitate poate fi recuzat de oricare dintre părți înainte de începerea oricărei dezbateri.”.

${ }^{54}$ În cadrul procedurilor arbitrale desfășurate în fața Curții Internaționale de Arbitraj de la Paris, părțile pot formula o cerere de recuzare împotriva unui arbitru atunci când acestea consideră că există suspiciuni referitoare la lipsa sa de imparțialitate sau de independență. A se vedea, 2021 Arbitration Rules and 2014 Mediation Rules, p. 26, [Online] la https:/iccwbo.org/content/uploads/ sites/ 3/2020/12/icc-2021-arbitration-rules-2014mediation-rules-english-version.pdf, accesat 21.11.2021.

55 În general, un astfel de atac presupune activitatea prin care un utilizator al unei platforme își creează multiple conturi de acces în cadrul acesteia și urmărește să influențeze modul în care platforma funcționează. În cadrul blockchain-ului, un astfel de atac presupune, de regulă, activitatea prin care o persoană urmărește să dețină controlul asupra mai multor calculatoare interconectate din baza de date şi, astfel, să modifice informațiile stocate. A se vedea, Sybil Attacks Explained, [Online] la https://academy.binance.com/ en/articles/sybil-attacks-explained, accesat 21.11.2021.

${ }^{56}$ A. Gudkov, op. cit., p. 71.

${ }^{57}$ Idem, p. 72. 
astfel, nici nu prezintă importanţă pentru cei ce soluţionează litigiul faptul că părţile provin din state diferite. Mai grav este faptul că, uneori, contractul dintre părţi chiar conţine o clauză de alegere a legii aplicabile, dar utilizatorii platformei nu ţin cont de aceasta şi soluţionează litigiul conform convingerilor proprii, ceea ce este de aşteptat, din moment ce nu toate persoanele ce se înrolează în cadrul acestor platforme au şi cunoştinţe juridice ${ }^{58}$.

Un alt dezavantaj este reprezentat de faptul că nu întotdeauna grăbirea sau accelerarea unei proceduri este şi eficientă. Din moment ce decizia pronunţată este una greşită, nu mai prezintă un avantaj soluţionare acesteia în regim de urgenţă. Principalul scop ar trebui să fie în continuare acela de a afla adevărul în cauză pentru a putea, ulterior, să fie soluţionată problema într-un mod corect. Astfel, în cadrul acestor proceduri, de cele mai multe ori nici nu sunt administrate probe, iar un litigiu în care nu sunt administrate probe nu poate fi soluţionat în mod temeinic. Din acest punct de vedere, este bine că se are în vedere celeritatea unei proceduri, dar acest lucru nu trebuie făcut în detrimentul aflării adevărului. Desigur, părţile îşi asumă toate aceste riscuri în momentul în care stabilesc de comun acord să recurgă la o asemenea procedură, iar faptul că obiectul litigiului are, de cele mai multe ori, o valoare redusă nu face decât să diminueze din riscurile asumate ${ }^{59}$.

\subsection{Modul în care sunt soluţionate litigiile în cadrul platformei Kleros}

Platforma Kleros a fost aleasă, ca studiu de caz, din două motive. În primul rând, este cea mai dezvoltată platformă $B D R$ ce oferă acces oricărei persoane interesate, nelimitând-se la o comunitate deja existentă în cadrul său ${ }^{60}$.

În al doilea rând, Kleros prezintă relevanţă datorită faptului că, în octombrie 2021, o instanţă statală din Mexic a recunoscut o procedură arbitrală desfăşurată în cadrul platformei, ceea ce demonstrează utilitatea şi importanţa Kleros. În acest sens, în anul 2020, într-un contract de leasing încheiat în Mexic, a fost introdusă o clauză arbitrală ce stabilea ca orice litigiu ulterior izvorât din acest contract să fie soluţionat de către un singur arbitru ales de către părţi. Totodată, clauza arbitrală stabilea şi modul în care urma să aibă loc procedura arbitrală, făcând referire la regulile platformei Kleros. La momentul apariţiei disputei, arbitrul desemnat de către părţi a trimis toate datele necesare platformei, iar, în cadrul acesteia, trei utilizatori au soluţionat litigiul. Pe baza deciziei luate de Kleros, arbitrul a pronunţat hotărârea arbitrală, iar, ulterior, în cadrul procedurii de recunoaştere a hotărârii, instanţa statală a recunoscut hotărârea pronunţată de arbitru în baza deciziei luate de platformă ${ }^{61}$.

${ }^{58}$ A. Gudkov, op. cit., p. 73.

${ }^{59}$ A. Gudkov, op. cit., p. 74.

60 În acest sens, în cadrul Kleros își desfășoară activitatea, la momentul redactării acestui articol, 767 de jurați, aceștia soluționând de-a lungul timpului peste 1000 de litigii. A se vedea, [Online] la https://kleros.io/, accesat 30.11.2021.

${ }^{61}$ M.V. Carrera, Accommodating Kleros As A Decentralised Dispute Resolution Tool For Civil Justice Systems: Theoretical Model And Case Of Application, p. 16, [Online] la 
Cel mai probabil, hotărârea instanţei statale s-a bazat pe hotărârea pronunţată de arbitru şi nu pe decizia luată în cadrul platformei. De altfel, o astfel de decizie nici nu are cum să facă obiectul unei proceduri de recunoaştere în fața unei instanţe statale. Dar, chiar şi aşa, hotărârea luată de către instanţa din Mexic prezintă importanţă pentru adepţii şi utilizatorii acestei modalităţi alternative de soluţionare a litigiilor.

Conform propriei descrieri, platforma Kleros reprezintă un spaţiu dedicat soluţionării alternative a litigiilor prin utilizarea blockchain-ului, ce oferă, prin intermediul serviciilor sale, o cale rapidă şi uşor de accesat pentru soluţionarea litigiilor în mediul online. Sintetizând modul în care este luată o decizie în cadrul Kleros, atunci când o problemă necesită a fi soluţionată, platforma apelează la utilizatorii înrolaţi în cadrul său (platforma foloseşte termenul de jurors - juraţi). Aceştia sunt traşi la sorţi, prin utilizarea unui algoritm, pentru a le fi repartizat respectivul litigiu şi, ulterior, juraţii iau o decizie în mod individual, fără a se consulta unul cu celălalt. Hotărârea este luată cu majoritatea voturilor exprimate. Utilizatorii ce au votat conform votului majoritar sunt remuneraţi, iar celorlalţi le este luată din propriul cont o anumită valoare calculată în cryptomoneda platformei. Odată luată, decizia este pusă în executare prin intermediul unui smart contract încheiat în momentul în care părţile au decis să recurgă la serviciile platformei ${ }^{62}$.

Atât numele Kleros, cât şi denumirea cryptomonedei, Pinakion, sunt preluate din sistemul folosit în Atena antică prin care erau selectaţi cei ce urmau să soluţioneze o problemă importantă pentru comunitate. Aceştia erau aleşi prin intermediul unui dispozitiv (un bloc de piatră), denumit kleroterion, în care cei ce doreau puteau introduce o plăcuţă ce conţinea numele lor, aceasta fiind denumită pinakia ${ }^{63}$.

Asemănările dintre platformă şi sistemul folosit în Atena acum 2000 de ani se opresc aici. Astfel, pentru ca un utilizator să poată să se înroleze în cadrul Kleros, el trebuie, mai întâi, să achiziţioneze o anumită valoare de cryptomonedă şi să depună această valoare în cadrul secţiunilor specializate din cadrul platformei ${ }^{64}$. Fiecare secţiune specializată (platforma foloseşte termenul de instanţă specializată)

https://ipfs.kleros.io/ipfs/QmfNrgSVE9bb17KzEVFoGf4KKA1Ekaht7ioLjYzheZ6prE/Accom modating\%20Kleros\%20as\%20a\%20Decentralized\%20Dispute\%20Resolution\%20Tool\%20for\%2 0Civil\%20Justice\%20Systems\%20-

\%20Theoretical\%20Model\%20and\%20Case\%20of\%20Application $\% 20$ -

\%20Mauricio\%20Virues\%20-\%20Kleros\%20Fellowship\%20of\%20Justice.pdf, accesat 23.11.2021.

${ }^{62}$ M. Dylag, H. Smith, op. cit., p. 6.

${ }^{63}$ Idem, p. 8; Kleroterion - Ensuring a fust Democracy, [Online] la https:// joyofmuseums.com/museums/europe/greece-museums/athens-museums/museum-of-theancient-agora/kleroterion/, accesat 25.11.2021; F. Ast, A. Sewrjugin, Crowdfury, a crowdsourced justice system for the collaboration era, p. 3, [Online] la https://www.researchgate.net/ publication/283687907_CrowdJury_a_crowdsourced_justice_system _

for_the_collaboration_era, accesat 25.11.2021.

${ }^{64}$ În momentul de față există opt secțiuni specializate, cărora li se alătură secțiunea ce are rolul de a soluționa căile de atac împotriva soluțiilor luate de către oricare dintre acestea. [Online] la https://court.kleros.io/courts, accesat 25.11.2021. 
prevede un prag diferit de cryptomonedă ce trebuie depusă. Odată ce este îndeplinită această condiţie, utilizatorii pot fi traşi la sorţi pentru a dobândi calitatea de jurat. Dar, modul în care sunt repartizaţi nu este neapărat unul aleatoriu. Inclusiv Kleros afirmă că utilizatorii ce au depus mai multă cryptomonedă au şanse mai mari de a fi traşi la sorţi. Fiind avantajaţi aceştia, platforma determină, indirect, o circulaţie sporită a propriei monede virtuale, crescând-i astfel valoarea ${ }^{65}$.

În momentul în care au fost traşi la sorţi, utilizatorilor li se blochează o anumită valoare de monedă virtuală. Ulterior, aceştia trebuie să soluţioneze litigiul şi în funcţie de votul majoritar şi de votul lor, respectiva sumă le este sau nu deblocată. Dacă votul acestora este conform votului majorităţii, suma le este deblocată şi, totodată, ei primesc şi un spor de eficienţă, dar dacă ei se află în minoritate, pierd suma blocată de către platformă. Practic, fiecare trebuie să identifice o soluţie în mod individual şi să mizeze pe faptul că şi ceilalţi vor ajunge la aceeaşi concluzie ${ }^{66}$.

$\mathrm{Cu}$ privire la acest mod de luare a deciziilor şi de remunerare a juraţilor sunt necesare câteva precizări. În primul rând, utilizatorii nu sunt remuneraţi în funcţie de munca depusă, ci în funcţie de decizia propusă. Practic, juraţii speculează care va fi decizia majoritară şi se aliniază acesteia. Acţiunea lor se aseamănă mai mult unei specule, decât unui mod de a soluţiona un litigiu în mod echitabil, ei urmărind să obțină un folos patrimonial, dar nu prin munca depusă, ci prin intermediul gradului de predictibilitate al soluţiei luate. În al doilea rând, din cauza modului în care sunt remuneraţi utilizatorii este pusă sub semnul întrebării corectitudinea deciziei luate. Ne putem imagina situaţia unui litigiu complex în care soluţia este mult mai greu de identificat. Iar o persoană care are cunoştinţe peste medie nu va vota conform propriilor convingeri, deoarece ea trebuie, practic, să intuiască care va fi decizia majoritară. Astfel, ea nu îşi va susţine punctul de vedere (ce poate fi corect) şi se va alinia unui punct de vedere majoritar deoarece urmăreşte să obţină profit din această acţiune.

Pe lângă discuţiile legate de corectitudinea deciziei, trebuie făcută o precizare şi cu privire la scopul urmărit de platformă. Prin modalitatea de atribuire a cauzelor utilizatorilor şi prin modalitatea de luare a deciziilor, Kleros urmăreşte creşterea circulaţiei propriei monede virtuale şi, astfel, creşterea valorii acesteia. Tocmai şi din această cauză le sunt atribuite cu precădere litigii pentru soluţionare utilizatorilor ce au depus mai multă cryptomonedă. Practic, majoritatea platformele $B D R$, nu doar Kleros, depind de gradul de circulaţie al monedelor virtuale create de către acestea ${ }^{67}$.

\footnotetext{
${ }^{65}$ M. Dylag, H. Smith, op. cit., p. 8.

${ }^{66}$ M. Dylag, H. Smith, op. cit., p. 9.

${ }^{67}$ Idem, p. 11.
} 


\section{Concluzii}

Mijloacele alternative de soluţionare a litigiilor au fost puternic influenţate de evoluţia tehnologică şi de expansiunea Internetului, iar utilizarea blockchain în soluţionare litigiilor nu vine decât să aducă un spor de noutate acestui domeniu.

Modul în care comunităţile blockchain regândesc actul de justiţie este unul inovativ. Practic, actul de justiţie este realizat, în cadrul acestor ecosisteme, prin intermediul crypto instanţelor ce iau hotărâri într-un mod descentralizat şi pun în executare hotărârile prin intermediul unor smart contracts.

Dar, nu orice noutate este şi eficientă. Deşi prezintă unele avantaje, utilizarea blockchain în soluţionarea litigiilor naşte, în mod clar, şi suficiente probleme. Din acest punct de vedere, indiferent cât de bine ar fi structurat un algoritm sau cât de bine pregătiţi ar fi unii utilizatori ai platformelor, ei nu se pot substitui în sarcinile unui judecător sau ale unui arbitru. Chiar şi dacă respectivii judecători sau arbitri pot greşi, indiferent cât se încearcă, inteligenţa artificială nu poate înlocui întrutotul factorul uman.

Dar asta nu înseamnă că tehnologia blockchain nu poate fi şi utilă. Ideal ar fi ca aceasta să fie utilizată cu scopul de a facilita procesul de soluţionare a unui litigiu şi nu cu scopul de a înlătura factorul uman decident. Iar, în aceste condiţii, progresul tehnologic nu poate fi decât unul de bun augur.

Totodată, asemenea tuturor domeniilor în care a fost utilizat blockchain-ul, viitorul acestui mod de soluţionare a litigiilor depinde, în primul rând, de utilizatorii platformelor. $\mathrm{Cu}$ cât există mai mulţi adepţi ai acestui mijloc, cu atât sunt mai multe şanse ca el să aibă succes pe termen lung.

\section{Referinţe}

Ast F., Sewrjugin A., Crowdfury, a crowdsourced justice system for the collaboration era, [Online]

Barnett J., Treleaven P., Algorithmic Dispute Resolution - The Automation of Professional Dispute Resolution Using AI and Blockchain Technologies, în The Computer Journal, Section C: Computational Intelligence, Machine Learning and Data Analytics, Vol. 61, Nr. 3, 2018, DOI: https://doi.org/10.1093/comjnl/bxx103

Carrera M.V., Accommodating Kleros As A Decentralised Dispute Resolution Tool For Civil Fustice Systems: Theoretical Model And Case Of Application, [Online]

Dimov D., Crowdsourced online dispute resolution, în Leiden University Center for Law and Digital Technologies, [Online]

Dylag M., Smith H., From cryptocurrencies to cryptocourts: blockchain and the financialization of dispute resolution platforms, în Information, Communication \& Society, [Online]

Gonzales W., Masumy N., Online Dispute Resolution Platforms: Cybersecurity Champions in the COVID-19 Era? Time for Arbitral Institutions to Embrace ODRs, în Kluwer Arbitration Blog, [Online]

Gudkov A., Crowd Arbitration: Blockchain Dispute Resolution, in Legal Issues in the Digital Age, Nr. 3, 2020, DOI: https://doi.org/10.17323/2713-2749.2020.3.59.77

Gupta V., A Brief History of Blockchain, în Harvard Business Review, [Online] 
Raymond A.H., Shackelford S.J., Technology, Ethics, and Access to fustice: Should an Algorithm be Deciding Your Case?, în Michigan Journal of International Law, Vol. 35, Nr. 3, 2014, [Online]

Rosencrance L., Loshin P., Cobb M., Two-factor authentication (2FA), [Online]

Seth S., UK Courts Start Pilot Blockchain Evidence System, [Online]

Stângaciu R.D., Limite ale implicării tehnologiei în soluţionarea prin mijloace alternative a litigiilor Online Dispute Resolution prin prisma raporturilor de comerţ internaţional, în Analele Ştiinţifice ale Universităţii „Alexandru Ioan Cuza” Iaşi, Tomul LXV, Ştiinţe Juridice, 2019, Supliment, [Online]

Ungureanu C.T., Dreptul comerţului internaţional, Editura Hamangiu, Bucureşti, 2018 